\title{
An Ambazonian theology? A theological approach to the Anglophone crisis in Cameroon
}

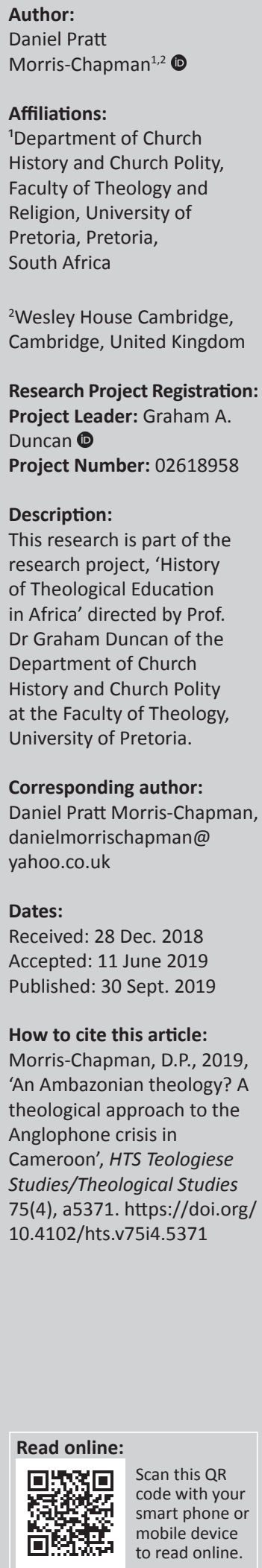

The last 3 years have witnessed a period of substantial volatility in Cameroon. In 2016, protests within the minority Anglophone regions against the obligatory use of French in schools triggered a period of considerable unrest, in which hundreds of people have been incarcerated and killed. Following an increased security presence in the English-speaking regions, armed groups have surfaced calling for secession - the creation of an independent nation of Ambazonia. In view of this escalating crisis, this article will investigate how the 'Anglophone problem' in Cameroon might be brought to bear upon the African theological debate by examining issues of violence, marginalisation and fragmentation within the two Englishspeaking areas of Cameroon.

Keywords: Ambazonia; Anglophone; Cameroon; Francophone; Liberation; Reconstruction; Inculturation.

\section{Introduction}

This article seeks to consider what kind of theological response might be appropriate to the Anglophone crisis in Cameroon. The 'Anglophone problem' has attracted significant attention since the 1980s (Konings 2003; Mukong 1990; Nyamnjoh 1997; Toh 2001; Victor 1999, 2004). Prior to this, there were also studies narrating Cameroon's multifaceted history (Ardener 1962; Gardinier 1963; Le Vine 1964) and the complex colonial roots of the present political impasse in the country (Benjamin 1972; Johnson 1970; Joseph 1977; Kale 1967). However, while there have been a number of political and historical analyses, the potential for an explicit theological treatment of this subject is yet to be fully explored. ${ }^{1}$

The distinctiveness of the Cameroonian context indicates that a particular form of theological reflection is needed. Unfortunately, while writers like Desmond Tutu have affirmed the need for 'a plurality of theologies' for the myriad of contexts and peoples within the continent (Tutu 1973, 1978:367-368), there are also those who have tried to limit the parameters of African theological discourse. While it is beyond the scope of the present enquiry to provide a comprehensive historical survey of African theology Oborji (2005), a classic illustration of this exclusivist tendency is found in Mbiti, who implied that black liberation theology was alien to the task of theological enquiry in Africa (1974:41-44). On the other side, there have been writers who have dismissed the ethnographic approach taken by (Mbiti 1986) as 'psychologically living in the past in order to escape from the harsh realities of the present' (Buthelezi 1973:31-32). ${ }^{2}$ A slightly different manifestation of this trend can be found in writers like Mana who consider that while combative forms of liberation theology were necessary 'at the time of the militant agitation from the 1960s to the 1980s, they are no longer sufficient as a paradigm of analysis within African theology (2002:93). However, while it may be true that certain African contexts no longer require theologians to engage in a revolutionary struggle for freedom, recent events in Cameroon indicate that the need for this type of methodological reflection remains acute.

Over the last 3 years there has been considerable unrest and violence (BBC 2017). Strikes within the minority English-speaking regions against the imposition of the French language in schools and court rooms have led to hundreds of people being arrested (Aljazeera 2016). Several people have been shot dead and the heads of various Anglophone churches were summoned to court for 1.Cardinal Archbishop Christian Tumi remains an exception to this. Although he does not survey the theological options in detail, he remains a powerful Christian voice in the political debate (Tumi 2011).

2.Other writers have attempted to synthesise these different emphases (Bujo 1999; Martey [1993] 2009).

Note: HTS 75th Anniversary Maake Masango Dedication.

Copyright: (C 2019. The Authors. Licensee: AOSIS. This work is licensed under the Creative Commons Attribution License. 
failing to open Church schools (Aljazeera 2017; Loh 2017). When protestors used Facebook and Twitter to highlight what they described as serious abuses by security forces, the government switched off the Internet in both the Englishspeaking regions (5 million people) for several months (France24 2017). This, combined with reports of sadistic brutality by government forces (Kouagheu 2018), has created a climate of violence in which armed Anglophone separatist groups - many of them young people (Amba Boys) - resorted to violence (even kidnapping civilians) and declared an Independent Republic of Ambazonia (Daily Telegraph 2018; UKGOV 2018).

Given current events, it would appear rash to dismiss certain theological emphases as outdated. Within the African theological landscape, there should be room for a wide variety of models. This surely comes with the vast terrain involved (Orobator 2009). Theological methods that have been dismissed by theologians in Cape Town (Villa-Vicencio 1992:49) may remain pertinent for ordinary people in Cameroon. ${ }^{3}$ Moreover, to presume that a new approach, however nuanced, will be applicable in every context is unrealistic. Thus, while it is important to highlight the variety of methodologies available, in exploring the potential for a theological response to the Anglophone crisis, it should be acknowledged that the particular focus of this investigation makes it imperative that Anglophone Cameroonian (AC) theological voices are given proper attention.

Having introduced the motivation for this study, the remainder of this article will explore what might constitute an appropriate theological response to the Anglophone crisis in Cameroon. For clarity, it is helpful at this juncture to list the main points that will be considered:

1. a discussion of the background to the Anglophone problem:

a. the marginalisation of Anglophones in Cameroon

b. a rising sense of Anglophone consciousness

c. the problem of fragmentation among the Anglophone community

2. a discussion of the possible theological responses to the Anglophone problem:

a. a brief introduction to some of the principal methods advanced within African theology

b. a discussion of Anglophone Cameroonian theologians in relation to these methods

3. an Ambazonian theology?

a. potential criticisms

b. Anglophone liberation or Ambazonian secession?

c. violent or non-violent resistance?

\section{Background of the Anglophone crisis}

The reasons for the present crisis may not be immediately obvious. Recent events may prompt those unfamiliar with the Cameroonian context to ask the following question: 'what given the contingent and partial nature of all theological enquiry (Dedji 2003). exactly is the Anglophone's problem? Why don't they just learn French?'4 For this reason, the article will begin with some background information to the problem, giving particular attention to issues such as marginalisation, division and identity over the last 50 years. It will then explore what might constitute an appropriate theological response to the current crisis.

At the outset it is necessary to explain the existence of two English-speaking regions within a mostly French-speaking state (Konings 2003:8). Essentially, like Canada, Cameroon is a country that has a large number of French- and Englishspeaking populations. Although it was a German protectorate (1884-1916), in 1919 a League of Nations mandate split Cameroon, stipulating that France should manage the East (80\%), while Britain should administer the West (20\%). This division continued until 1961 when the nation was reunited, becoming the Federal Republic of Cameroon - giving English- and French-speaking Cameroonians a share in the political power. ${ }^{5}$ However, within a decade (1972), the federal system was discontinued and Cameroon became a unitary state - with power centred in the East (Nkwain 2013:23). ${ }^{6}$

\section{Marginalisation}

In Cameroon, decolonialism did not bring about an end to oppression but instead brought about what the Francophone Cameroonian (FC) Philosopher Achille Mbembe refers to as a 'becoming Black of the world' (2017a:5), whereby Anglophones became a category of inferior people who could be exploited (Gerber 2018:165). Hence, following independence from the European powers, the governments of Ahmadou Ahidjo and Paul Biya (Ahidjo's successor) consolidated Francophone dominance (Dongmo 2008:49; Kah 2010:28-31). ${ }^{7}$ This has manifested itself in a variety of ways. Government investment in education, healthcare, roads, industry and even electricity generation has been centred in the Eastern French-speaking areas. Most of the infrastructure in the Western Anglophone side of the country was built before (1961) reunification - and it is fast crumbling (Mbaku 2004:404-405). Before reunification there were three airports, two seaports and a river port in British Southern

4.When I presented an earlier draft of this paper (2015), I was asked this very question by a leading figure in contemporary African theology. The example of the Soweto by a leading figure in contemporary African theology. The example of the Soweto uprising (June 1976) might have afforded a helpful response to his question. During apartheid, the imposition of Afrikaans - the language of the oppressor - as a medium of instruction in South African schools provoked a series of protests and other forms of organised resistance which eventually brought the apartheid regime to its knees (SAHO 2018; Stubbs 1987:143). While English, which was used as a medium of education prior to this, is not an indigenous language of the people of South Africa, it was more widely known than Afrikaans. In a comparable way, while English is not an indigenous Cameroonian language, Anglophones have interpreted the imposition of the French language - which for them is a language of oppression in the nation's schools and courts as the final straw in a long history of Anglophone marginalisation (Aljazeera 2016).

5.The Anglophones had requested that they should be given the option of becoming an independent nation but this option was not given to them by the British government.

6.Achille Mbembe (2001, 2017a) articulates how a betrayal of the vision of independence, and the subsequent economic devastation that follows, has created the kinds of regimes typified in so many postcolonial states (Bongmba 2016:284).

7.In 1998 and 1999 Cameroon was deemed to be the most corrupt country in the world (BBC 2018). 
Cameroons - all of these were closed after reunification (Anyefru 2010:96) ${ }^{8}$

For 30 years after independence, until the University of Buea was founded (1992), it was impossible to pursue higher education in English medium (Mbaku 2004:404-405). There is widespread discrimination: few political offices are given to Anglophones. Positions in government - the civil service, the military and the police force - are given to Francophones - even the ambassadors and high commissioners appointed to serve in English-speaking countries like Nigeria, the USA and the UK are Francophones.

Furthermore, government offices within the Anglophone regions, the courts and even the post office use French medium. In effect, English-speaking Cameroonians are being marginalised - they are second-class citizens in a Francophone-dominated nation. This situation is often referred to as the 'Anglophone problem' (Anyefru 2010:86).

\section{Anglophone consciousness?}

The marginalisation of the English-speaking regions has provoked an interesting response. According to Gifford (1998):

The anglophones have become particularly strident in their denunciation of [Paul] Biya's government which they tend to dismiss as totally corrupt and incompetent. Their contempt has grown in tandem with a curious romanticizing of their British colonial legacy. (p. 247)

Anyefru clarifies that this community views itself as being distinctive not only because it has its own official language but also because it has inherited Anglo-Saxon traditions of public administration, law and education. The 'educational, legal, administrative, political, governance and institutional culture and value systems are all English-derived' (Anyefru 2010:86-87). This inheritance has been jealously guarded in the face of a concerted government effort to destroy the cultural and institutional foundations of these regions. Nevertheless, this attempt to '[ $g$ ]allicise the Anglophone cultural heritage' has only served to galvanise these people, hardening their zeal to retain what Konings describes as an 'Anglophone identity' (2003:9-11, 56). Likewise, Anyefru considers that there is a 'rising Anglophone consciousness' within these regions (2010:86-87).

\section{Fragmentation among Anglophones}

In view of the above, it is unfortunate that ethnoregional tensions within the English-speaking community have often hindered Anglophones from making a united challenge against their marginalisation (Konings 2003:2, 8). The two Anglophone zones are referred to as the northwest (savannah) and southwest (coastal forest) regions. It is important to acknowledge that these areas possess considerable linguistic and cultural diversity. The geographical complexity, particularly in the mountainous areas within these regions, 8.These facilities were closed so as to increase dependence on the east. has led to the development of countless indigenous languages (Kouega 2007, 2011:44-58; Lewis 2009). ${ }^{9}$ In addition, societies within the grasslands (northwest) were highly centralised, whereas in the coastal region chieftaincy was a much weaker institution (Konings 2003:13-16).

During the colonial era it was common for differences of this nature to be exaggerated in order to prevent opposition to the imperial power. According to the FC Philosopher Achille Mbembe (2016):

In a colonial context, this constant effort to separate (and thus to differentiate) was partly a consequence of an anxiety of annihilation felt by the colonizers themselves. Numerically inferior but endowed with powerful means of destruction, the colonizers lived in perpetual fear of being surrounded on all sides by 'evil objects' threatening their very survival and existence.

As a result of this, the colonial strategy involved the deliberate fragmentation of a territory into local administrative regions containing a single culturally and linguistically homogeneous group where people were governed indirectly through local structures of authority (Berman 1998:315). This practice was widely used in northern Cameroon where the French authorities divided the territory into regions, subregions and cantons to limit the political influence of the indigenous peoples so as to prevent them from overwhelming the limited coercive resources available to the Europeans (Drønen 2013:182-183). As a northerner, Ahidjo would have been very familiar with this strategy. Thus, when Cameroon became a republic (1972), Ahidjo formalised the ethnoregional boundaries by dividing the federal state of West Cameroon into two separate provinces (north and southwest). This allowed him to capitalise on the ethnoregional diversity contained within the state of West Cameroon. This master stroke successfully turned the Anglophones into rivals (Kah 2012:71ff). The government of Paul Biya has successfully continued these divide and rule tactics in order to thwart Anglophone solidarity (Konings 2003:13-16).

From the above it is apparent that decades of marginalisation have reinforced an Anglophone identity in Cameroonians originating from the north and southwest regions of the country. However, it has also been noted that Anglophone fragmentation (particularly ethnic division) has at times served to prevent them from offering a united response to these problems. Therefore, having briefly surveyed the contours of the Anglophone crisis, it is now necessary to question what, of some of the different possibilities available, might constitute the most appropriate theological response to this problem.

\section{Possible theological responses to the Anglophone problem}

Within African theological debates there are a plethora of important themes, including inculturation, liberation 9.Cameroon is one of the most multilingual countries in Africa (Kouega 2007:3-93). 
and reconstruction. A number of writers, emphasising the legitimacy of African culture, have focussed upon the integration of Christian identity with their rich cultural and religious heritage (Bediako 1990, 1994:14-20; Mbiti 1974:41-44)..$^{10}$ Liberative African theologies take a variety of different forms - including South African Black theology (Motlhabi 2008:9; Tshaka \& Makofane 2010), ${ }^{11}$ African women's liberation theology (Oduyoye 2001) (2) $^{2}$ and many others - and these writers seek to address sociopolitical, economic, racial, cultural and gender-based forms of oppression afflicting the continent (De La Torre 2015). Another group, emphasising reconstruction, considers that these earlier approaches have served their purpose and that what is needed now is a proactive approach that will focus on how to restore African nations economically, culturally and politically (Mana 1993; Mugambi 1995; Villa-Vicencio 1992). As was indicated earlier, in exploring the relevance of these African approaches to theology for the Anglophone crisis in Cameroon, it is important to give detailed attention to the perspective of AC theologians. Nevertheless, FC theologians will also be acknowledged in so far as their work is relevant to this matter.

\section{Inculturation}

Several FC theologians have explored the theme of inculturation (Atangana 2006; Ewane 1965, 1969; Fossouo 2010; Hebga 1976, 1998; Lado 2006, 2009, 2016; Ngome 2014; Obianga 1995). Though theological publications by Anglophones have been scarce, ${ }^{13}$ there is a growing body of literature on this subject. For example, Catholic and Protestant theologians from the southwest region, including Ntetem (1987) and Ebong (2010, 2015), have attempted to use indigenous concepts to reframe various aspects of the Christian tradition. Likewise, theologians from the northwest, such as Kofon (1992), Muyo (2001, 2002), Fochang (2004) and Nyuyki (2016) have also explored how traditions originating in their region might complement Christian understandings of marriage, atonement, hymnody and doxology. While these proponents of inculturation do not engage with the Anglophone problem, Augustine Nkwain, a Roman Catholic theologian from the northwest region, mentions this issue.

Nkwain, an Anglophone Roman Catholic theologian from the northwest, argues that, given the enormous difficulties facing contextual theologians in a country with over 200 languages, it is very important that different ethnic groups do not become polarised into competing interest groups (2013:66-67, 155).

10.John Mbiti's writing offers a classic example of this emphasis in African theology (Mbiti 1986)

11.Manas Buthelezi offers a paradigmatic example of this emphasis (Buthelezi 1973:29-35).

12.African Women's Theology can also be classified as a separate category of theological discourse as, while it encourages critical reflection upon established cultural practices, it seeks to remain African in identity. Nevertheless, its liberative emphasis clearly qualifies it as a form of liberation theology (Oduyoye 2001).

13.This is partly because for many years it has been impossible to study theology to $\mathrm{PhD}$ level within Cameroon in the medium of English.
Pointing out how important it is for Anglophones to be united - 'division cripples the opposition' - Nkwain emphasises that theologians must balance the needs and identity of the many different tribes $(2013: 171)^{14}$ so as to prevent inculturation from encouraging ethnocentrism (2013:46-47, 171). However, though Nkwain is correct to identify this difficulty, his attempt to mitigate against it does not correspond with the gravity of the current situation unarmed civilians being burnt alive (Maclean 2018a) - which has deteriorated considerably since his analysis was published (Maclean 2018b). Here it is possible that insights from the South African context might be helpful. During apartheid, black South African theologians resisted the indigenisation paradigm because they recognised that one of the tools employed by the apartheid regime to ensure white supremacy was to exaggerate differences within the black population. According to Motlhabi, for '[b]lack theologians to have preached indigenisation at the time would have been to play into the hands of the authors of apartheid' (Motlhabi 2008:9). Given the divide and rule strategy employed by successive Cameroonian governments, it is hard to see how a theological method which could inadvertently amplify people's differences would be the optimum choice at a time when Anglophones need to unite against oppression. Having probed the appropriateness of the inculturation paradigm, it is important to explore whether or not theologies emphasising liberation might be more pertinent at present.

\section{Liberative theologies}

A variety of theologies may be classified as liberative (De La Torre 2015), and within the Cameroonian context the same variety can be found..$^{15}$ For example, in a manner comparable to other writers (Zimmermann 2002), a number of Cameroonians have integrated the themes of inculturation and liberation together (Atangana 2006:20; Metogo 1997:33-45; Nyiawung 2013). ${ }^{16}$ For example, Engelbert Mveng, an accomplished anthropologist and Roman Catholic FC theologian, considered that Africans have been impoverished anthropologically and materially (1994:156). ${ }^{17}$ For this reason, he repeatedly stressed the need for the church to challenge both the anthropological and structural mechanisms of poverty across the continent (1996). The work of Jean Marc-Ela, a Roman Catholic FC, whose theological

14.Nkwain applies Ruth Cohn's 'Theme-Centred Interaction' to the Cameroonian situation and considers that this method will help balance the needs between one cultural group and that of another (Cohn 2006).

15.These also include studies on the empowerment of African women (Atem 2011; Lang 2016) and the liberation theology of HIV and/or AIDS (Neba 2015; Salla 2006). Regarding the latter group, Jean-Bertrand Salla, FC Roman Catholic theologian, challenges the violation of human rights by corrupt political regimes which have compounded the problem of poverty and HIV and/or AIDS. For theologians like Salla, a key question is ' $[w]$ ho is Christ to an African continent that is dying from AIDS and living with HIV?' (2006:92). For further discussion, see Chitando (2009:123) and Dube (2008:50).

16.A German missionary, writing in one of the few theological journals published in Anglophone Cameroon, has also argued for a combination of inculturation and liberation: 'in principle every theology must be contextual ... and every theology must be liberating' (Zimmermann 2002:6).

17.While Mveng's L'Afrique dans L'Eglise (1985) stressed the need for inculturation and represents one of the very first calls for an African council, his Theologie Liberation et Cultures Africaines (1996) emphasised the need for a combination of both economic and anthropological liberation in African contexts like Cameroon. 
writings have been cited as a paradigmatic example of liberation theology (Gifford 1998:269), also contains these two themes (1998:10-11). For example, Ela argued that a recovery of the African church's cultural heritage was not enough and maintained that the church must translate both the Bible and the 'fundamental laws of our land' so that everyone can know their 'rights as citizens' (1988:9). Thus, while affirming the importance of anthropological liberation, Ela believed that the oppression facing Africans was more urgent than recovering an African identity (1986:102, 135, 1988:173, 1994:140). ${ }^{18}$

One potential criticism of these writers is that while they were proponents of liberation they did not address the Anglophone problem in any detail. However, a possible reason for this might be that Ela and Mveng originated in the Francophone region and thus would not directly experience the effects of Anglophone marginalisation. Nevertheless, any criticism of these writers must be tempered by the fact that both suffered greatly for speaking the truth to power (Gifford 1998:271). ${ }^{19}$

Anglophone theological voices on this matter are also scarce. The most detailed analysis by an Anglophone of the relationship between liberation theology and the Cameroonian context is given by Prof. Wan-Tatah (Youngstown Ohio State University). His work, Emancipation in African Theology (1989), offers a comprehensive discussion of both the origins of liberation theology and of the Nso' context from which he originates (in the northwest region of English-speaking Cameroon). Wan-Tatah argues that a liberation theology for Africa must give serious consideration to African culture (1989:129-130). However, while he acknowledges that the Marxist critique of capitalism can be useful in diagnosing the evils of multinational companies and former colonial powers, he considers certain atheistic aspects of this methodology limiting and restrictive for the African context (1989:176-177). He argues that the African world view, its concepts of God and its rituals must also be used as instruments for liberation by reaffirming the African person and her dignity (1989:147). However, the fundamental problem with Wan-Tatah's analysis is that it gives only a brief mention to the Anglophone problem and its causes (1989:80,167). This impairs his analysis - particularly as one of the key reasons for the persistence of the Anglophone problem is the manipulation of cultural diversity within the English-speaking regions. The divide and rule strategy that has been employed by the state suggests that the use of African culture as an instrument of liberation in the Cameroonian Anglophone context may only accentuate divisions.

18.Like Ela and Mveng, Fabien Boulaga FC philosopher (former Catholic) has also been categorised as a proponent of this liberation/inculturation synthesis. Nevertheless, while emphasising that Christianity must be conceptually born again in the African situation (Bousing 1986) Boulaga is uncomfortable with the term 'inculturation' situation (Boulaga 1986), Boulaga is uncomfortable with the term 'inculturation because it implies that culture is a static thing: 'a paleontological entity to be restored from fossilized remnants and folklore' (Boulaga 2014:9). If human being produce cultures, it is people that should be the central focus. However, while
discussing Anglophone tensions, he does not relate these to the question of the direction of Cameroonian theology (Boulaga 1997).

19.Mveng was murdered and Ela was forced into exile.
Similar criticisms might be made of Prof. Elias Bongmba, an Anglophone based at Rice University (Texas). For example, he has published a work focusing on theological responses to the HIV and/or AIDS crisis in Cameroon (2007).${ }^{20}$ However, while this work discusses Cameroon and details how a 'climate of political and economic injustice creates conditions which promote the spread of HIV/AIDS', it is not explicit about the Anglophone problem - despite the fact that this has certainly compounded poverty in the northwest region where much of Bongmba's research is carried out (2007:53). ${ }^{21}$ Nevertheless, it is important to acknowledge that Bongmba is highly critical of political oppression in Africa generally and his book Dialectics of Transformation offers a detailed philosophical analysis of the challenges facing the continent (2006:46-47). For instance, he argues that while the colonial legacy cannot be ignored, the chief cause of these problems is poor leadership in that nations, which has been used as a vehicle for private gain by selfish rulers who have centralised power in and for themselves (2006:46ff). Moreover, his observations on how African leaders, including Ahidjo and Biya, have manipulated ethnic rivalries are helpful (2006:13, 30, 131).

Nevertheless, while Bongmba uses Cameroon and other contexts to illustrate these points, the Anglophone problem is not the focus of this work and, while implicit, is not addressed in any detail (2006:59-60).

One exception to this trend is the work of Cardinal Archbishop Christian Tumi, from the northwest of Cameroon, who has censured writers who disregard the Anglophone problem (2016a). He has been a steadfast critic of the Cameroonian government and has repeatedly advocated for a return to the federalism initially agreed upon at reunification (Gifford 1998:268; Tumi 2017). His writings evidence a profound commitment to justice (Tumi 2006:159-170) and might be classified as liberation theology. ${ }^{22}$ However, while his writings are clearly liberative in emphasis, Tumi is not quick to encourage citizens to topple the government (Tumi 2011:168) and has recently requested that armed separatists 'lay down their arms' and 'become peace builders' (2018). Moreover, Tumi is firmly against tribalism (2016b) and continues to emphasise that all Cameroonians 'are one people united in diversity' (2006:120).

\section{The theology of reconstruction}

Tumi's general concern for Cameroon's political restoration resonates with the theme of reconstruction in African theology (Bongmba 2016:285). In his work A Theology of

20.The South African theologian Tinyiko Maluleke has argued that 'a theology of HIVI AIDS is the face of a new "theology of liberation"' (Maluleke 2001:134).

21.Similar points might be made of his excellent theological reflection upon the ongoing prevalence of Witchcraft in Africa (Bongmba 2001).

22.This liberative emphasis is indicated in a number of ways. For example, The Political Regimes condemns the misrule of Ahidjo and Biya, indicating how their rules have created and prolonged the Anglophone crisis in Cameroon (2006:159). Tumi's My Faith condemns the oppression of Anglophones by the Cameroonian state (2011:38). Moreover, Tumi is one of the first African Catholic bishops to support (2011:38). Moreover, Tumi is one of the first African Catholic bishops to support
the idea that married couples might use condoms to prevent the spread of HIV and/or AIDS (Bongmba 2016:283-304). 
Reconstruction, Villa-Vincencio tried to locate the theological principles involved in the process of political reconstruction (1992:74). Here he argued that post-apartheid South Africa resembles the post-exilic period in Israel's history (1992:27). For this reason he considered that the emphasis needs to shift from liberation to reconstruction so as to create a constructive theology of nation-building (1992:49). While he acknowledged that South Africa was likely to continue to live between the times for several decades and, moreover, stressed that the church should not rest until all structural and residual forms of oppression are eradicated from the statute books, he nevertheless argued that at this stage in the nation's history it is necessary to no longer retain a victim mentality (1992:30, 46, 74). He warned that the failure to move forward could have devastating consequences. For example, during apartheid the law was an implementation of an oppressive regime and a liberation theology supporting organised resistance against the government was right and just. However, he considers that in the post-apartheid situation, nation-building theologians should stress that the law can be an instrument of restitution and justice and should encourage people to uphold the law (1992:51).

Writing from the Kenyan context, Mugambi likewise argues that Africa has entered a new historical phase now that 'institutionalized racism, formal colonialism, and cold-war tutelage' have reached their 'end'. He argues that the release of Nelson Mandela from prison, and its implications for South Africa and the rest of the continent, requires an 'appraisal of the theologies of liberation and inculturation' which had shaped African theology previously (1997:3). He thus believes that the role of the theologian is now to challenge Africa to 'rebuild its own ruins - from the rubble of crumbled walls and broken societies' (2003:1). For this reason, he proposes that the 'figure of Nehemiah' offers a paradigmatic example of 'a leader who represents the aspirations and contradictions of Africa's social reconstruction at this time in history' (2003:2-3). Thus, while Mugambi considers that the rediscovery of Africa's cultural and religious heritages will provide all the ingredients necessary for its social reconstruction, he does not believe that the inculturation paradigm is sufficient. His writing instead emphasises the need for Africans to unite together (1997:6). $\mathrm{He}$ is a supporter of the pan-Africanism and argues that Africans must be one if they are to transcend the social political and economic challenges faced by the continent (1997:3-7). In summary, he considers that if Africa could affirm its 'political, economic and cultural' unity and form an internal market for goods and services, it would resolve its current marginalisation in the world (1997:7-9).

In evaluating these themes, Bongmba considers that Tumi's critical engagement with the state, and his critical perspective on the social and political context in Cameroon, resembles the theology of reconstruction (Bongmba 2016:285). While Tumi (2011) does not explicitly take this position, the theme of reconstruction is implicit in his writing, particularly in his desire for Cameroonians to create a united country:

This country would be something else than what it is today if Cameroonians from north to south, from east to west, Anglophones or Francophone realized that we are brothers and sisters and capable of loving instead of hating, of uniting instead of dividing, or practicing justice and peace instead of injustice and violence, of pardoning instead of having the desire to revenge. (p. 179)

In this vein, Tumi's work might be interpreted as an attempt to restore rather than divide Cameroon. Furthermore, like Villa-Vincencio, while he is quick to challenge the abuse of power, he has strongly encouraged Cameroonians to realise their constitutional liberty and maintain justice at all levels of society (Tumi 2006:159-170). Hence, rather than calling for secession, Tumi's work appears to seek the reconstruction of the country as a whole.

This type of theological orientation is also present in FC writers (Essome 1980; Pondi 1997). For example, Pondi has suggested that the challenges facing Africa require a comprehensive political, economic and spiritual reconstruction of Africa by Africans. While he does not reject the inculturation or liberation paradigm altogether, he warns that Africans should not lock 'ourselves in our past' and is very critical of the ideological underpinning of revolutionary movements (1997:45-46). This perhaps explains why Pondi (2016), although he does not discuss his reconstructive theological orientation in relation to the Anglophone problem, has strongly criticised secessionists who seek the creation of a separate Ambazonian nation through revolutionary means.

There is great value in the theme of reconstruction and it would be foolish to dismiss its relevance for Cameroon. Nevertheless, it is all too easy to make a theological prescription derived for one African context into a continent-wide solution. Critics of this approach have pointed out that while some African countries are now free of despotism and tyranny, and are in a position to rebuild their nations, people living in other nations are still suffering oppression. For example, the South African theologian Tinyiko Maluleke argues that these 'theologies of reconstruction ... jump too quickly from Egypt to Canaan, from exile to post-exile - skipping the meandering and long sojourn in the wilderness' (2005:495-496). Maluleke's comments resonate with Francophone writers like Pondi whose recent essay Is there an Anglophone Problem in Cameroon or Could it be a Fantasy? grossly underestimates the level of humiliation, discrimination and marginalisation experienced daily by Anglophones in Cameroon (Pondi 2016). This criticism should not be interpreted as a comprehensive rejection of the theology of reconstruction. The points advanced by these writers are highly pertinent for this African context and when the current crisis in Cameroon comes to an end, regardless of whether or not 
this could lead to the secession of the Anglophone regions, there will need to be a concerted emphasis upon reconstruction. However, while there is clearly a time for everything, at present the current crisis shows no signs of abating. This indicates that a liberation theology of organised resistance against the current regime may well be pertinent.

\section{An Ambazonian theology?}

Is there a need for an Anglophone liberation theology whose sole purpose is to apply the liberating power of the gospel to their situation? To my knowledge, none of the writers above have explored the creation of a distinctive theology of this kind - a confrontation between the gospel and the Anglophone crisis (Cone 1969:31-32). While there have been a number of Cameroonian theologians who have utilised the theme of liberation, few of these writers discuss the oppression of Anglophones. Moreover, those who address the problem do not appear to support the secession of Ambazonia. ${ }^{23}$ However, given the brutal killing of many innocent people, is an Ambazonian theology necessary - a liberation theology supporting organised resistance against the government? In exploring these questions, it should be acknowledged that the distinctiveness of the Cameroonian context may require us to look at some unexpected places so that we can draw upon the riches of the wider tradition of liberation theology.

\section{Potential criticisms of this theological proposal}

Opponents of a proposal of this nature may ridicule the idea of a theology permeated by an Anglophone consciousness. Critics might argue that Anglophones are not a distinct people group as they only exist as a result of the colonial legacy. For example, although he does not discuss the possibility of an Ambazonian theology of liberation, the FC Philosopher Mbembe argues that the idea of an Anglophone state is absurd (Mbembe 2017b). He considers that the storm over language is a symptom of a deeper problem in that under both Ahidjo and Biya there has been a 'francophonisation' of the whole of the Cameroon, causing the nation's institutions and political culture to be saturated by a French political model. Nevertheless, he maintains that by categorising its dissent in terms of an 'Anglophone' identity - an identity connected with the colonial heritage protestors have obscured the real underlying problem. He maintains that what is truly needed is the decolonisation of Cameroon as a whole - to 'de-francophonise' Cameroon. Hence, for Mbembe, the solution is for there to be a decolonised, multicultural, multinational and democratic Cameroon (Mbembe 2001, 2017b).

23.There is profound resistance to the secession of Ambazonia. For example, unlike many other churches, the Roman Catholic Church has managed to remain united across this divided country and Catholic writers appear to be more supportive of across this chice country and Catholic write 2017b. 2017b, Oboe 2008, Tumi 2011.179). However, while Francophone Catholic Aneolo Anglophone region, referring to Ambazonia as a "monstre" brought about by opportunists (2017), the fact remains that many ordinary Anglophone men and women explicitly desire secession (Essomba 2018).
There are a number of problems with Mbembe's analysis. ${ }^{24}$ For example, while he is correct to identify the root cause of Anglophone marginalisation as the endurance of an aggressive postcolonial Francophone mentality in the nation's leaders, bent upon assimilating minority groups, this fact does not necessarily preclude the secession of Ambazonia - or the creation of an Ambazonian theology of liberation. ${ }^{25}$ Moreover, while Mbembe is right to identify the awkward (un-African) colonial roots of an Anglophone conception of identity, his assessment does not rule out the creation of a specific form of liberation theology centred upon this marginalised group. ${ }^{26}$ For example, the same criticism might also be made of Dalit (liberation) theology.

The outside observer might enquire why Dalit Christian liberation theologians have chosen to identify themselves using a derogatory non-Christian concept, signifying their marginalisation in a majority 'Hindu society ... historically marked by a rigid form of social stratification' (Michael 1999:75; Sadangi 2008:25)? In response to this question, these writers argue that:

The term Dalit is revelatory to Dalits and non-Dalits of a situation of oppression. Attempts to change the terms because they are of reproach is only an exercise in evading the problem. (Devasahayam 1997:18)

The argument here is that the experience of being Dalit in an oppressive social system should be named so that people can be conscientised of the reality. As a result, the term does not remain an alien category of discrimination but instead becomes 'a term of protest' against the caste system. Dalit identity is thereby transformed into an 'anti-caste identity' and becomes something new and different - independent of Hindu conceptions - a positive expression of hope (Haokip 2014:259). The same points might be made concerning an Anglophone consciousness. To paraphrase Haokip, the very realisation of themselves as Anglophone might be a means towards their liberation (2014:259). Therefore, by identifying as Anglophones - and categorising their rebellion in terms of an Anglophone dissent - they reveal a sense of belonging to a 'unified class, or movement seeking emancipation' (Michael 1999:6). According to this way of thinking, the term 'Anglophone' is renewed. It ceases to be a colonial category

24.While Mbembe's points are astute, it is unlikely that any people group will renounce the culture or language that they have been formed within - even if it is a culture influenced by a colonial power. For this reason, it would seem that his analysis is disconnected from the reality of daily life for Cameroonians. analysis is disconnected from the reality of daily life for Cameroonians.
Furthermore, he is not an Anglophone and, having spent much of his life outside of Cameroon, acknowledges his disconnectedness from his home country. He describes himself as 'a citizen of nowhere in particular ... Belonging to nowhere in particular, I have become my own home, a portable house I take with me wherever particular, I have become my own home, a portable house I take with me wherever
I happen to find a roof. I have to find a center that is not tangible, some form of interiority that gives me a sense of inner stability amidst the turbulence and vagaries of where life takes me. This state of permanent motion and fugitiveness has become an important dimension of the way I think' (Oboe 2008).

25.Furthermore, while Mbembe's observations - regarding the need to jettison the inheritance of a European cultural curse - are significant, it is clear that language is intrinsically connected to culture (Geertz 1973; Kroeber 1968:102). While it would be imprudent to conflate language with culture (Whorf 1956), it is clear that language divides reality into 'conceptual space' (Chríost 2003:13). Thus, given these points, it is not at all surprising that English-speaking Cameroonians might feel a sense of identity in relation to their having a shared language.

26. For instance, even if it were true that the notion of an Anglophone identity remains nothing more than a vestige of the colonial legacy, the term 'Ambazonian' has become a marker of identity - a category of political identification and belonging in the face of government oppression. 
and becomes a unifying concept - a tool enabling an oppressed people to realise their freedom.

There is a world of difference between India and Cameroon. Nevertheless, like Anglophones in Cameroon, Dalits in India suffer oppression from their fellow countrymen. While Dalit Christian theologians have decided to continue using the concept Dalit (which has connotations of Hindu oppression) as a template for their variant of liberation theology so might Anglophone Christians utilise the concept Anglophone (with its own connotations of colonial oppression) to explore what the Christian gospel might have to say to men and women, whose existence is daily threatened by the state (Cone 1997:16-17). Therefore, having indicated this possibility, it is necessary to explore how the paradigm of liberation theology might be applied in this context.

\section{Anglophone liberation or Ambazonian secession?}

The situation in Cameroon is deteriorating every day. In a recent report (June 2019), the General Secretary of the Norwegian Refugee Council has said that if nothing changes, 'full-blown war' will be unavoidable (Egeland 2019). What does liberation mean in this setting? ${ }^{27}$ Can freedom be realised if Anglophones remain a part of Cameroon, or does liberation entail secession? There are no simple answers here. Unlike the South African context, in which the majority were able to obtain political power by physically overcoming the apartheid regime, the situation in Cameroon is perhaps more analogous to that faced by African Americans who, as a minority, have had little option but to reform their political context from within - obtaining their civil rights through a nonviolent struggle. Therefore, while black South African liberation theology successfully integrated organised violent resistance, it would appear that the (ongoing) physical struggle with the Cameroon state (which has for many years been supported by France) is unlikely to bring about liberation for Anglophones (Hopkins 1989:xi-xii). ${ }^{28}$

This raises the question as to whether or not Anglophones in Cameroon should follow the pattern of black American liberation theologians, resist violence and struggle to remain a part of Cameroon in the hope that it will one day be possible to be both an Anglophone and a Cameroonian 'without being cursed and spit upon by his fellows' or 'losing the opportunity of self-development' (Du Bois 1897)? ${ }^{29}$ Anglophones might be encouraged to transform their society from within demanding their rights through the courts and struggling to lobby for the restoration of a federal political system by

27.1 am thankful to one of my students for challenging me to examine this question more fully.

28.The possibility of success is not ruled out altogether here. Historically, there have been examples in which a minority has, against all the odds, miraculously obtained victory (Mitchell 1853:285-297).

29. Within the tradition of black liberation theology it has been erroneously suggested that 'while black Americans continually undergo the tug between their Americanness and the nagging question mark about their African heritage' Africans do not experience this type of double consciousness (Hopkins 1989:xii). On the contrary, AC writers like Ngwa have insisted that Anglophones in Cameroon experience 'multiple conscioussness' (Ngwa 2018:52). They are Cameroonians but they are Anglophones. nonviolent means (Cone 1989:100; Hopkins 1989:xi-xii; Rabaka 2008:151-152). However, while there are clearly parallels between these minority groups, the political settings in which their respective struggles are carried out remain totally different. For this reason it is doubtful whether this approach would be practicable.

Neither of these liberative approaches resonate entirely with the problem under discussion. Cameroon is not America. The legal system in Cameroon is unlikely to bring Anglophones justice - especially given the fact that legal proceedings are now conducted in a language (French) many do not understand. Moreover, while violent organised resistance may prove futile, it is evident that Anglophone citizens cannot stand by and watch their villages being razed to the ground by the security forces. This raises the question as to whether or not a combination or synthesis of these approaches may be relevant for liberation theologians in this context.

\section{Violent or nonviolent resistance?}

Firstly, given the brutal killing of many innocent people by the state, it would appear that a liberation theology supporting organised resistance against the government is needed. However, it is necessary to explore what, in this context, organised resistance might imply. After all, 'it is simply not true to say that every possible use of physical force is violence and that no matter what the circumstances may be it is never permissible' (Kairos Document 1985). The burning of hundreds of villages by the government, the displacement of half a million people, the acts of violence and rape committed by the state against ordinary citizens (Egeland 2019) surely require a response:

This is not to say that any use of force at any time by people who are oppressed is permissible simply because they are struggling for their liberation. There have been cases of killing and maiming that no Christian would want to approve of. But then our disapproval is based upon a concern for genuine liberation and a conviction that such acts are unnecessary, counter-productive and unjustifiable and not because they fall under a blanket condemnation of any use of physical force in any circumstance. (Kairos Document 1985)

In this sense, it is regrettable that the use of force may at certain times be required if Anglophones are to obtain their liberty. In this sense an authentic AC theology of liberation should bear in mind that the 'moral illegitimacy' of the current regime means that Christians:

will have to be involved at times in civil disobedience. A Church that takes its responsibilities seriously in these circumstances will sometimes have to confront and to disobey the State in order to obey God. (Kairos Document 1985)

This would imply a conditional support of those engaged in organised resistance against the Cameroonian state.

Secondly, in a manner comparable to the strategy employed in the United States, Anglophones should be encouraged to pursue their grievances through legal means. Thus, while 
the legal system in Cameroon is notoriously corrupt, the pursuit of emancipation and justice through international courts should surely be encouraged by AC theologians. While there is profound resistance to the secession of Ambazonia, it is clear that Anglophones themselves should be afforded the chance (denied to them by the British government) to vote on whether or not they want to become a separate sovereign nation. Francophones who would ridicule the idea of a free and independent Ambazonia (Lado 2017; Mbembe 2017b), who find time to discuss whether or not the Anglophone problem even exists (Pondi 2016), should try to imagine what it feels like 'to be a problem', an 'outcast and a stranger in mine own house' (Du Bois 1897). These FC theologians would be more usefully employed in petitioning the international community on behalf of their oppressed Anglophone brothers and sisters in Christ. There is certainly an acute need for this activism. According to Egeland, ' $[t]$ he international community is asleep at the wheel when it comes to the crisis in Cameroon. Brutal killings, burneddown villages and massive displacement have been met with deafening silence' (June 2019).

\section{Conclusion}

This article does not presume to have an answer to all these questions. Neither does it seek to formulate an Ambazonian theology for university professors and scholars to debate (Cone 1973:48, 1989:100). ${ }^{30}$ It is instead intended to clear the theological space for ordinary men and women to pursue their liberation from oppression - to suggest that a liberation theology would be coherent and relevant to Anglophones in Cameroon. Nevertheless, there are clearly a number of different approaches available to AC theologians and it would be unwise to exclude any of the emphases discussed over the longer term.

However, given the divide and rule strategy employed by successive Francophone governments, it would appear that an exclusive focus on the theme of inculturation could potentially be counter-productive at this moment in time. Moreover, while there is clearly scope for a theology of reconstruction in this setting, it could be premature to formulate such an approach in view of the continued suppression of constitutional freedoms and the ongoing brutality faced by ordinary citizens. For these reasons, and this should not be interpreted as an eternal prescription, it is argued that the creation of an Anglophone theology of liberation - focussed upon what the gospel of Christ means for oppressed Anglophone men and women - should be the focus at this particular time. It is hoped that an Anglophone/ Ambazonian theology of this kind might bolster organised resistance in a manner comparable to that of South African black theology during the time of apartheid. ${ }^{31}$

30.This article was conceived while teaching a course on African theology in Cameroon when I found a half-eaten copy of James Cone's (1970) work in a local library.

31.I dedicate this article to all my brothers and sisters in Cameroon and express my gratitude to the Transatlantic Round Table on Religion and Race inspiring me to develop this article.

\section{Acknowledgements}

The author would like to thank Graham Duncan, Mike Brealey, Lilian Dube and Tinyiko Maluleke for their comments on earlier drafts of this article.

The author dedicates this article to all his brothers and sisters in Cameroon and expresses his gratitude to the Transatlantic Round Table on Religion and Race for inspiring him to develop the paper he presented (London 2015) into the present article.

\section{Competing interests}

The author declares that no competing interest exists.

\section{Authors' contribution}

M.S. is the sole author of this article.

\section{Ethical consideration}

This article followed all ethical standards for carrying out research without direct contact with human or animal subjects.

\section{Funding Information}

This research received no specific grant from any funding agency in the public, commercial or not-for-profit sectors.

\section{Data availability statement}

Data sharing is not applicable to this article as no new data were created or analysed in this study.

\section{Disclaimer}

The views and opinions expressed in this article are those of the author and do not necessarily reflect the official policy or position of any affiliated agency of the author.

\section{References}

Aljazeera, 2016, Cameroon teachers, lawyers strike in battle for English, viewed 05 December 2016, from https://www.aljazeera.com/news/2016/12/cameroonteachers-lawyers-strike-english-161205095929616.html.

Aljazeera, 2017, Cameroon shuts down internet in English-speaking areas, viewed 26 January 2017, from https://www.aljazeera.com/news/2017/01/cameroonanglophone-areas-suffer-internet-blackout-170125174215077.html.

Anyefru, E., 2010, 'Paradoxes of internationalisation of the Anglophone problem in Cameroon', Journal of Contemporary African Studies 28(1), 85-101. https://doi. org/10.1080/02589000903542624

Ardener, E.W., 1962, 'The political history of Cameroon', The World Today 18(8), 341-350.

Atangana, D.E., 2006, 'Christ in the Black Messianisms of Africa', Concilium 2006(4), 15-21.

Atem, G., 2011, 'Women's empowerment for leadership positions within the Presbyterian Church in Cameroon: A missiological exploration', Unpublished MTh thesis, University of KwaZulu-Natal, SA.

BBC, 2017, 'Why has Cameroon blocked the internet', viewed 08 February 2017, from http://www.bbc.com/news/world-africa-38895541.

BBC, 2018, 'Cameroon country profile', viewed 22 October 2018, from https://www. bbc.com/news/world-africa-13146029.

Bediako, K., 1990, Jesus in African culture, Asempa, Accra.

Bediako, K., 1994, 'Understanding African theology in the twentieth century', Themelios 20(1), 14-20. 
Benjamin, J., 1972, Les Camerounais Occidentaux: la minorite dans une tatbicommunautaire University Press, Montreal.

Berman, B., 1998, 'Ethnicity, patronage and the African state: The politics of uncivil nationalism', African Affairs 97(388), 305-341. https://doi.org/10.1093/ oxfordjournals.afraf.a007947

Bongmba, E.K., 2001, African Witchcraft and Otherness: A philosophical and theological critique, State University Press, Albany, NY.

Bongmba, E.K., 2006, The dialectics of transformation in Africa, Macmillan, New York.

Bongmba, E.K., 2007, Facing a pandemic: The African church and the crisis of aids, Baylor, Waco, TX.

Bongmba, E.K., 2016, 'Church and State in Cameroon: The political theology of Christian Cardinal Tumi', Journal of Asian African Studies 51(3), 283-304. https:// doi.org/10.1177/0021909615612110

Boulaga, F.E., 1986, Christianity without fetishes: An African critique and recapture of Christianity, Orbis, Maryknoll, NY.

Boulaga, F.E., 1997, La democratie de transit au Cameroun, L'Harmattan, Paris.

Boulaga, F.E., 2014, Muntu in crisis, Africa World Press, London.

Bujo, B., 1999, African theology in its social context, transl. J. O'Donohue, Pauline Publications, Nairobi.

Buthelezi, M., 1973, 'An African theology or a Black theology', in B. Moore (ed.), Black theology: The South African voice, pp. 29-35, Hurst \& Company, London.

Chitando, E., 2009, Troubled but not destroyed, WCC Publications, Geneva.

Chríost, D.M.G., 2003, Language, identity and conflict, Routledge, London.

Cohn, R. (ed.), 2006, In der balance liegt die Chance, W Munster, Berlin.

Cone, J., 1969, The Gospel of Jesus, Black People, and Black Power, Seabury Press, New York.

Cone, J., 1973, 'Black theology and Black liberation', in B. Moore (ed.), Black theology: The South African voice, pp. 48-57, Hurst \& Company, London.

Cone, J., 1997, God of the oppressed, Orbis, Maryknoll, NY.

Cone, J.H., 1970, Liberation: A Black theology of liberation, J P Lippincott, New York.

Cone, J.H., 1989, 'Theological reflection on black theology', in S. Maimela (ed.) We are one voice: Black theology in the USA and South Africa, pp. 97-104, Skotaville, Johannesburg.

Daily Telegraph, 2018, '78 school children kidnapped in Cameroon', viewed 04 December '208, from https://www.telegraph.co.uk/news/2018/11/05/eightypeople-mostly-children-kidnapped-cameroon/.

De La Torre, M.A. (ed.), 2015, Introducing liberative theologies, Orbis Books, Maryknoll, NY.

Dedji, V., 2003, Reconstruction and renewal in African Christian theology, Acton Publishers, Nairobi.

Devasahayam, V., 1997, Doing Dalit theology in biblical key, Gurukul Lutheran Theological College Press, Chennai, India.

Dongmo, C., 2008, 'The building of a dictatorship', Cameroon Journal on Democracy and Human Rights 2(1), 41-50.

Drønen, T.S., 2013, Pentecostalism, globalisation and Islam in Northern Cameroon Brill, Leiden.

Du Bois, W.E.B., 1897, Strivings of the Negro people, viewed 01 June 2019, from https://www.theatlantic.com/magazine/archive/1897/08/strivings-of-the-negropeople/305446/.

Dube, D., 2008, The HIV \& AIDS Bible. Selected essays, University Press, Scranton, PN.

Ebong, L.E., 2010, 'In Search of African Christianity', Voices from Kumba 3(1), 132-140.

Ebong, L.E., 2015, Living African traditions and customs in Jesus Christ, Erscheinungsdatum, Frankfurt.

Egeland, J., 2019, Cameroon tops list of most neglected crises, viewed 05 June 2019, from https://www.nrc.no/news/2019/june/cameroon-tops-list-of-mostneglected-crises/.

Ela, J., 1986, African cry, Orbis, Maryknoll, New York.

Ela, J., 1988, My faith as an African, Orbis, Maryknoll, New York.

Ela, J., 1994, 'Christianity and liberation in Africa', in R. Gibellini (ed.), Paths of African theology, pp. 136-150, SCM, London.

Essomba, F., 2018, Cameroon English Speakers Fight to Break Away, viewed 11 December 2018, from https://www.nytimes.com/2018/06/28/world/africa/ cameroon-secession.html.

Essome, K., 1980, 'Reviving the tradition of city building in Africa', in H. Bandmann (ed.), The Industrialization of Africa, pp. 41-49, Campaigner, Wiesbaden.

Ewane, F.K., 1965, Eléments d'anthropologie africaine, Droit Canonique, Strasbourg.

Ewane, F.K., 1969, La présence africaine (Eglise d'Afrique) aux conciles de Vatican I (1869-1870) etVatican II (1962-1965), Droit Canonique, Strasbourg.

Fochang, B.G., 2004, 'An exploration of the conception of god among the Bali Nyonga and its impact upon their contemporary Christian practice with particular reference to Hymnody and Prayer', Unpublished PhD thesis, University of KwaZulu-Natal, SA.

Fossouo, P., 2010, 'Approche nouvelle des royautés sacrées africaines', in M. Cheza (ed.), Théologiens etthéologiennes dansl 'Afriqued' aujourd'hui, pp. 105-116, Karthala, Paris.
France24, 2017, 'Three months after pulling the plug, Cameroon restores internet to anglophone region', viewed 21 April 2017 from http://www france24.com/ en/20170421-cameroon-restores-internet-english-anglophone-region-biya.

Gardinier, D.E., 1963, Cameroon: United Nations challenge to French policy, University Press, Oxford.

Geertz, C., 1973, The interpretation of cultures, University Press, Chicago, IL.

Gerber, S.H., 2018, 'Critique of Black reason: Rethinking the relation of the particular and the universal', Journal of World Philosophies 3(Summer), 165-168. https:// doi.org/10.2979/jourworlphil.3.1.13

Gifford, P., 1998, African Christianity: Its public role, Hurst \& Company, London.

Haokip, J., 2014, Can God save my village?: A theological study of identity among the Tribal People of North-East India, Langham Monographs, Carlisle.

Hebga, M., 1976, Emancipation d'Eglises Sous-tutelle, Présence Africaine, Paris.

Hebga, M., 1998, La rationalité d'un discours africain sur les phénomènes paranormaux, L'Harmattan, Paris.

Hopkins, D., 1989, 'Introduction', in S. Maimela (ed.) We are one voice: Black theology in the USA and South Africa, pp. ix-xix, Skotaville, Johannesburg.

Johnson, W.R., 1970, The Cameroon Federation: Political integration in a fragmentary society, University Press, Princeton, NJ.

Joseph, R.A., 1977, Radical nationalism in Cameroun, University Press, Oxford.

Kah, H.K., 2010, 'The culture of appointments, arrogance, and Chop Broke Pottism in Cameroons' contemporary governance', Cameroon Journal on Democracy and Human Rights 2(1), 41-50.

Kah, H.K., 2012, 'The Anglophone Problem in Cameroon', Cameroon Journal on Democracy and Human Rights 6(1), 71-103.

Kairos Document, 1985, 'A theological comment on the political crisis in South Africa', viewed 05 June 2019, from https://kairossouthernafrica.wordpress. com/2011/05/08/the-south-africa-kairos-document-1985/.

Kale, P., 1967, Political evolution in the Cameroons, Government Print, Buea.

Kofon, N.E., 1992, Polygny in pre-Christian Bafut and new moral theological perspectives, Peter Lang, Frankfurt.

Konings, P., 2003, Negotiating an Anglophone identity, Brill, Leiden.

Kouagheu, J., 2018, Cameroon probes video showing security forces apparently executing civilians, viewed 04 December 2018, from https://www.reuters.com/ article/us-cameroon-security-video/cameroon-probes-video-showing-securityforces-apparently-executing-civilians-idUSKBN1KV224.

Kouega, J.P., 2007, 'The language situation in Cameroon', Language Planning 8(1), 3-93. https://doi.org/10.2167/cilp110.0

Kouega, J.P., 2011, 'Multilingual practices in Presbyterian Churches in Cameroon' International Journal of Innovative Interdisciplinary Research 8(1), 44-58.

Kroeber, A., 1968, The nature of culture, University of Chicago Press, Chicago, IL.

Lado, L., 2006, 'African Catholicism in the Face of Pentecostalism', Concilium 2006(4), $22-30$.

Lado, L., 2009, Catholic Pentecostalism and the Paradoxes of Africanization: Processes of localization in a Catholic Charismatic movement in Cameroon, Brill, Leiden.

Lado, L., 2016, le jésuite qui n'a pas sa langue dans sa poche, viewed 01 January 2018 from https://www.jeuneafrique.com/mag/334811/societe/ludovic-lado-jesuitena-langue-poche/.

Lado, L., 2017, Crise Anglophone et Strategies de Diabolisation par Ludovic, viewed 19 February from https://jetcamer.com/36741/jn/crise-anglophone-et-strategiesde-diabolisation-par-ludovic-lado.html.

Lang, M.K., 2016, 'Women and Christianity in Cameroon: The case of the Presbyterian church in Cameroon since the Basel Mission era, 1886-2010', Afro Asian Journal of Social Sciences 7(4), 1-24.

Le Vine, V., 1964, The Cameroons: From Mandate to Independence, University Press, Los Angeles, CA.

Lewis, P., (ed.), 2009, Ethnologue: Languages of the world, SIL International, Dallas, TX

Loh, C., 2017, Anglophone crisis: Catholic, PCC, CBC Leaders Summoned to Court, viewed 21 April 2017, from https://www.cameroon-tribune.cm/articles/7825/fr/ anglophone-crisis-catholic-pcc-cbc-leaders-summoned-to-court.

Maclean, R., 2018a, Cameroon Military accused of burning alive unarmed civilians, viewed 11 December 2018, from https://www.theguardian.com/world/2018/ $\mathrm{jul} / 20 /$ cameroon-military-accused-of-burning-alive-unarmed-civilains-villagesenglish-speaking.

Maclean, R., 2018b, Violence in Cameroon's Anglophone Regions Spiralling out of Control, viewed 11 December 2018, from https://www.theguardian.com/ world/2018/sep/18/cameroon-amnesty-election-violence-anglophoneregions.

Maluleke, T.S., 2001, 'The challenge of HIV/AIDS for theological education in Africa. Towards an HIV/AIDS sensitive curriculum', Missionalia 29(2), 125-143.

Maluleke, T.S., 2005, 'African theology', in D. Ford (ed.), The modern theologians, pp. 485-501, Blackwell, Oxford.

Mana, K., 1993, Theologie Africaine, Karthala, Paris.

Mana, K., 2002, Christians and churches of Africa envisioning the future, Regnum, Edinburgh. 
Martey, E., 1993 [2009], African theology: Inculturation and liberation, Wipf\& Stock, Eugene, OR.

Mbaku, J.M., 2004, 'Economic dependence in Cameroon: SAPs and the Bretton Woods agreement', in J. Mbaku \& J. Takougang (eds.), The leadership challenge in Africa: Cameroon under Paul Biya, pp. 404-405, Africa World Press, Trenton.

Mbembe, A., 2001, On the postcolony, University of California Press, Berkerley, CA.

Mbembe, A., 2016, The society of enmity, viewed 11 December 2018, from https:// www.radicalphilosophy.com/article/the-society-of-enmity.

Mbembe, A., 2017a, Critique of Black reason, transl. L. Dubois, Duke University Press, Durham, NC.

Mbembe, A., 2017b, Cameroun - Crise anglophone: Pour Achille Mbembe, viewed 12 December 2018, from https://www.cameroon-info.net/article/cameroun-criseanglophone-pour-achille-mbembe-la-dissidence-anglophone-naurait-pas-duformuler-ses-282342.html.

Mbiti, J., 1974, 'An African views American Black theology', Worldview 17 August, pp. 41-44.

Mbiti, J., 1986, Bible and theology in African Christianity, University Press, Oxford.

Metogo, E.M., 1997, Dieu peut-il mourir en Afrique, Karthala, Paris.

Michael, S.M., 1999, Untouchable: Dalits in Modern India, Boulder, London.

Mitchell, A.W., 1853, The Waldenses, Presbyterian Publications, Pensylvania, PA.

Motlhabi, M., 2008, African theology/Black theology in South Africa, University of South Africa Press, Pretoria.

Mugambi, J.N.K., 1995, From liberation to reconstruction: African Christian theology after the Cold War, East African Educational Publishers, Nairobi.

Mugambi, J.N.K., 1997, 'Social Reconstruction of Africa', in J Mugambi (ed.) The church and reconstruction in Africa, pp. 1-25, AACC, Nairobi.

Mugambi, J.N.K., 2003, 'Foreword', in M. Getui \& E. Obeng (eds.), Theology of reconstruction: Exploratory essays, pp. 1-3, Acton, Nairobi.

Mukong, A., 1990, The case for the Southern Cameroons, Camfeco, Enugu.

Muyo, J.N., 2001, 'The Scapegoat Sacrifice in Leviticus 16 and the Nefo'o ritual of the Bafut of Cameroon', Unpublished PhD thesis, University of Stellenbosch, SA.

Muyo, J.N., 2002, 'African perspectives on the decalogue: The eight commandment You shall not steal', Voices from Kumba 1(1), 113-123.

Mveng, E., 1985, L'Afrique dans L'Eglise: Paroles d'un Croyant, L'Harmattan, Paris.

Mveng, E., 1994, 'Impoverishment and liberation', in R. Gibellini (ed.), Paths of African theology, pp. 154-165, SCM, London.

Mveng, E., 1996, Theologie, Liberation et Cultures Africaines: Dialogue sur l'anthropologie Negro-Africaine, Presence Africaine, Yaounde.

Neba, W., 2015, 'Rights and the common good: An ethical evaluation of the exercise of the natural right of HIV/AIDS patients to marry in the light of the Common good", Unpublished PhD thesis, The Catholic University of America.

Ngome, H.E., 2014, Parenté Ethnoculturelle del'Égypte Ancienneet du Monde Bantu, Menaibuc, Paris.

Ngwa, K., 2018, 'Postwar hermeneutics', in T. Siong \& B. Liew (eds.), Colonialism and the Bible: Contemporary reflections from the global South, pp. 43-74, Lexington Books, London.

Nkwain, A.N., 2013, Cultural diversity and its challenges to evangelization in Cameroon: A multidisciplinary approach with Pastoral focus of a church in multicultural African Society, Peter Lang, Frankfurt.

Ntetem, M., 1987, 'Initiation, traditional and Christian', in J. Parratt (ed.), A reader in African Christian Theology, pp.103-109, SPCK, London.

Nyamnjoh, F.B., 1997, 'The Anglophone problem in Cameroon', The Journal of Modern African Studies 35(6), 208-229. https://doi.org/10.1017/S0022278X97002401

Nyiawung, M.D., 2013, 'An African hermeneutic reading of Luke 9:18-22 in relation to conflict and leadership in pastoral ministry: The Cameroonian context', HTS Teologiese Studies/Theological Studies 69(1), Art. \#1201, 1-9. https://doi. org/10.4102/hts.v69i1.1201

Nyuyki, P., 2016, 'Syncretism and inculturation in the Nso context of Cameroon' Stellenbosch Theological Journal 2(2), 381-400. https://doi.org/10.17570/ stj.2016.v2n2.a18

Obianga, R.Z., 1995, 'The encounter of Gospel and culture in the experience of an African woman', International Review of Mission 84(334), 295-297. https://doi. org/10.1111/j.1758-6631.1995.tb02709.x
Oboe, A., 2008, Africa and the night of language: An interview with Achille Mbembe, viewed 12 December 2018, from https://jwtc.org.za/the salon/volume 2/ annalisa_oboe_africa_the_night_of_language.htm.

Oborji, F.A., 2005, Trends in African theology since Vatican II: A missiological orientation, Leberit Press, Rome.

Oduyoye, M.A., 2001, Introducing African women's theology, Academic Press, Sheffield.

Orobator, A.E., 2009, 'The sky is wide enough: A historico-critical appraisal of theological activity and method in Africa', Hekima Review 40(5), 34-44.

Pondi, J.E., 1997, 'The political economy of Africa's reconstruction', in J. Mugambi (ed.), The church and reconstruction in Africa, pp. 40-48, AACC, Nairobi.

Pondi, J.E., 2016, Is there an "Anglophone Problem" in Cameroon or could this be a mere Fantasy?, viewed 30 May 2019, from https://www.facebook.com/ permalink. php?story_fbid=1157624854359106\&id=789972304457698.

Rabaka, R., 2008, Du Bois's Dialectics: Black radical politics and reconstruction, Lexington Books, London.

Sadangi, H.C., 2008, Dalit: The Downtrodden of India, Isha Books, Delhi.

SAHO, 2018, The June 16 Soweto Youth Uprising, viewed 10 December 2016, from https://www.sahistory.org.za/topic/june-16-soweto-youth-uprising.

Salla, J., 2006, 'Historic churches and family and sexual morality', Concilium 2006(4), $87-95$.

Stubbs, A., 1987, SteveBiko 1946-1977-I Write what I like: A selection of his writings, Heinemann, Oxford.

Toh, N.P., 2001, The Anglophone problem in Cameroon, Quality Printers, Bamenda.

Tshaka, R.S. \& Makofane, M.K., 2010, 'The continued relevance of Black liberation theology for democratic South Africa today', Scriptura 105, 532-546. https://doi. org/10.7833/105-0-155

Tumi, C., 2006, The political regimes of Ahmadou Ahidjo and Paul Biya, and Christian Tumi, Priest, Pitambar Publishing House, Delhi.

Tumi, C., 2011, My faith: A Cameroon to be renewed, Éditions Veritas, Douala.

Tumi, C., 2016a, Cardinal Tumi condemns Philemon Yang, says there is an Anglophone problem, viewed 10 December 2016, from https://www.cameroonconcordnews. com/cardinal-tumi-condemns-philemon-yang-says-there-is-an-anglophoneproblem/.

Tumi, C., 2016b, Cardinal Tumi condemns tribalism, viewed 21 October 2016, from https://www.cameroonconcordnews.com/cardinal-tumi-condemns-tribalismsays-he-does-not-believe-in-regional-balance/.

Tumi, C., 2017, Anglophone crisis: Cardinal Tumi condemns arrest of consortium leaders, viewed 25 January 2017, from https://www.cameroonintelligencereport. com/anglophone-crisis-cardinal-tumi-condemns-arrest-of-consortium-leaders/.

Tumi, C., 2018, Cameroon: Tumi pleads with Ambazonia fighters to drop weapons, viewed 06 December 2018, from https://www.journalducameroun.com/en/ cameroon-tumi-pleads-with-ambazonia-fighters-to-drop-weapons/.

Tutu, D.M., 1973, 'Black theology/African theology-Soul Mates or antagonists?', The Journal of Religious Thought 32(2), 25-33.

Tutu, D.M., 1978, 'Whither African theology', in E. Fashole-Luke \& R. Gray (eds.), Christianity in Independent Africa, pp. 364-369, Rex Collins, London.

UKGOV, 2018, Cameroon, viewed 04 December 2018, from https://www.gov. uk/foreign-travel-advice/cameroon?utm_source=7fdee76f-6efd-46aa-b874f5e28780ec8e\&utm_medium=email\&utm_campaign=govuk-notifications\&utm content=immediate.

Victor, J.N., 1999, 'The origin of the marginalization of former Southern Cameroonians (Anglophones) 1961-1966: An historical analysis', Journal of Third World Studies 91, 165-183.

Victor, J.N., 2004, Cameroon: From a federal to a unitary state 1961-1972, Design House, Limbe.

Villa-Vicencio, C., 1992, A theology of reconstruction: Nation-building and human rights, University Press, Cambridge.

Wan-Tatah, V., 1989, Emancipation in African theology: An inquiry on the relevance of Latin American Theology to Africa , Peter Lang, New York.

Whorf, B., 1956, Language, thought, and reality: Selected writings of Benjamin Lee Whorf, MIT Press, Cambridge, MA.

Zimmermann, A., 2002, 'Introduction: Doing theology in Cameroon', Voices from Kumba 1(1), 6-12. 